\title{
Karakterisasi Geoteknik Fondasi Kandidat Tapak PLTN dengan Metode Seismik Refraksi
}

\section{Foundation Geotechnical Characterization of Candidate Nuclear Power Plant Site using Seismic Refraction Method}

\author{
Dwi Haryanto*, Yoshi Rachael, Dhatu Kamajati, Gagah Hari Prasetyo, \\ Heri Syaeful, Frederikus Dian Indrastomo \\ Pusat Riset dan Teknologi Bahan Galian Nuklir - ORTN-BRIN \\ Jl. Lebak Bulus Raya No. 9, Pasar Jumat, Jakarta 12440, Indonesia \\ *E-mail: antox@batan.go.id
}

Naskah diterima: 17 November 2021, direvisi: 27 November 2021, disetujui: 30 November 2021

DOI: 10.17146/eksplorium.2021.42.2.6538

\begin{abstract}
ABSTRAK
Pemerintah Indonesia dalam Peraturan Presiden (Perpres) Nomor 38 Tahun 2018 tentang Rencana Induk Riset Nasional Tahun 2017-2045, menetapkan beberapa bidang utama yang akan menjadi prioritas penelitian nasional, salah satunya adalah bidang energi. Dalam tema riset teknologi kelistrikan berbasis energi baru dan terbarukan rendah/nol karbon terdapat topik riset teknologi Pembangkit Listrik Tenaga Nuklir (PLTN) skala komersial. Pada topik riset tersebut, ditetapkan bahwa dalam jangka waktu penelitian tahun 2020-2024, dihasilkan purwarupa PLTN. Pada penelitian ini, karakterisasi geoteknik tapak PLTN dilakukan dengan menggunakan metode seismik refraksi guna melengkapi data penelitian sebelumnya. Tujuan penelitian ini adalah untuk mengetahui profil perlapisan batuan bawah permukaan untuk estimasi pekerjaan terkait fondasi PLTN. Pemetaan geologi dan akuisisi data geofisika, pengolahan, serta interpretasi tanah/batuan berdasarkan parameter kecepatan gelombang kompresi $(\mathrm{Vp})$. Hasil pemetaan geologi menunjukkan adanya 2 satuan batuan beku yaitu diorit kuarsa dan andesit. Hasil pengolahan dan interpretasi data seismik refraksi menghasilkan model penampang $\mathrm{Vp}$ pada lapisan batuan bawah permukaan. Terdapat 3 lapisan batuan di lokasi penelitian yaitu lapisan tanah (Vp $=361-715 \mathrm{~m} / \mathrm{s})$, lapisan batuan beku lapuk $(\mathrm{Vp}=1.386-2.397 \mathrm{~m} / \mathrm{s})$, dan lapisan beku segar $(\mathrm{Vp}=3.789-6.133$ $\mathrm{m} / \mathrm{s})$. Perkiraan densitas batuan beku segar berdasarkan perhitungan adalah $2,43-2,74 \mathrm{~g} / \mathrm{cm}^{3}$. Hasil pemodelan dapat menunjukkan kedalaman dan struktur bawah permukaan lapisan batuan beku segar yang dapat menjadi fondasi bangunan PLTN.
\end{abstract}

Kata kunci: tapak PLTN, karakterisasi geoteknik, seismik refraksi, fondasi

\begin{abstract}
Presidential Regulation (Perpres) number 38 of 2018 concerning the National Research Master Plan for 2017-2045, the Government of Indonesia establishes several main areas that will become national research priorities, one of which is the energy sector. In the research theme of electricity technology based on new and renewable low/zero carbon energy, there is the topic of research on commercial-scale Nuclear Power Plant (NPP) technology. On the research topic, it was determined that within the research period of 2020-2024, a prototype nuclear power plant would be produced. Research related to the geotechnical characterization of the nuclear power plant site using the seismic refraction method was carried out to complement the previous research data. The purpose of this study was to determine the subsurface rock layer profile for estimation of work related to nuclear power plant foundations. Geological mapping and geophysical data acquisition, processing, as well as soil/rock interpretation based on the compression wave velocity (Vp) parameter are carried out to achieve this goal. The results of geological mapping show that there are 2 igneous rock units, namely quartz diorite and andesite. The results of processing and interpreting seismic refraction data produced a cross-sectional model of $V p$ in the subsurface rock layers. There are 3 rock layers in the research location, namely soil layer (Vp $=361-$
\end{abstract}


$715 \mathrm{~m} / \mathrm{s})$, weathered igneous rock layer $(V p=1.386-2,396 \mathrm{~m} / \mathrm{s})$, and fresh igneous layer $(\operatorname{Vp}=3.789-6.133 \mathrm{~m} / \mathrm{s})$. The estimated density of fresh igneous rock based on calculations is $2.43-2.74 \mathrm{~g} / \mathrm{cm}^{3}$. The modeling results can show the depth and structure of the subsurface layer of fresh igneous rock that can be the foundation of nuclear power plants.

Keywords: NPP site, geotechnical characterization, seismic refraction, foundation

\section{PENDAHULUAN}

Penelitian karakterisasi geoteknik fondasi tapak dengan metode seismik refraksi merupakan salah satu implementasi Perpres Nomor 18 Tahun 2020 tentang Rencana Pembangunan Jangka Menengah Nasional (RPJMN) Tahun 2020-2024 (Pemerintah Republik Indonesia, 2020), terutama yang terkait dengan peningkatan kapabilitas pada kelompok strategi pemanfaatan IPTEK dan penciptaan inovasi di bidang fokus RIRN 2017-2045. BRIN mendukung Prioritas Riset Nasional (PRN) dengan melakukan studi tapak PLTN Bengkayang, Kalimantan Barat, khususnya dalam aspek geologi, geoteknik, dan geofisika.

Beberapa penelitian terdahulu terkait daerah minatan di Pulau Kalimantan telah dilakukan baik di Kalimantan Timur [1], maupun di Kalimantan Barat [2]-[4]. Hasil penelitian menunjukkan daerah di sekitar Pantai Gosong, Desa Sungai Raya, Kecamatan Sungai Raya Kepulauan, Kabupaten Bengkayang dapat menjadi calon tapak potensial untuk PLTN [4]. Pemerintah Provinsi Kalimantan Barat mengusulkan daerah Pantai Gosong sebagai calon tapak sehingga direncanakan suatu program Prioritas Riset Nasional (PRN). Beberapa penelitian lanjutan terkait tapak telah dilakukan di lokasi minatan seperti untuk analisis risiko [5], persepsi masyarakat dan potensi penerimaan publik [6], potensi bahaya gunung api [7], serta perubahan tata guna lahan [8], [9]. Lokasi penelitian ditunjukkan oleh Gambar 1.

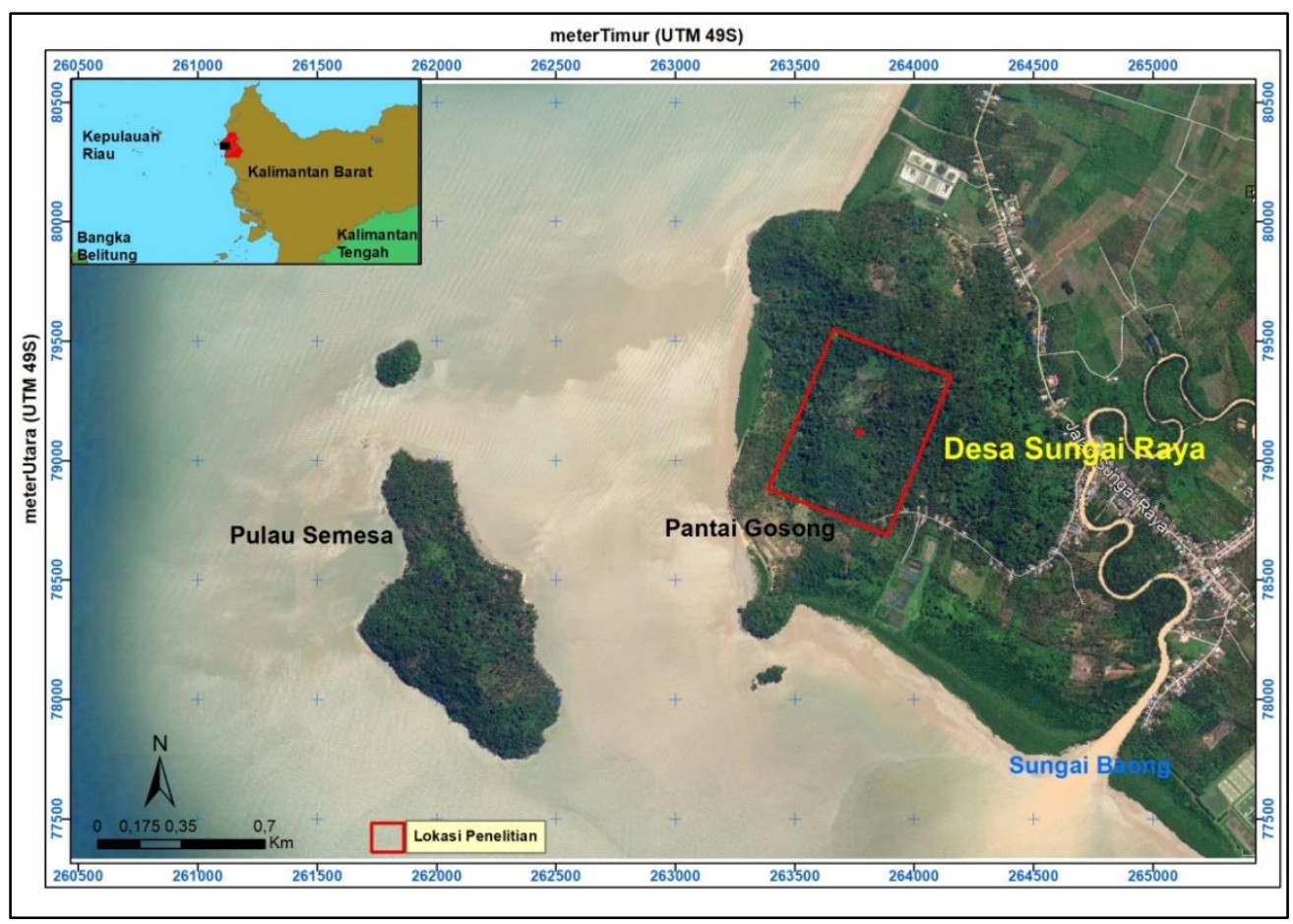

Gambar 1. Lokasi penelitian di daerah Pantai Gosong, Desa Sungai Raya. 
Karakteristik geoteknik fondasi merupakan salah satu unsur penting untuk menentukan keselamatan PLTN. Desain PLTN salah satunya bergantung pada karakteristik geoteknik fondasi. Data geoteknik yang telah ada hingga saat ini adalah data geoteknik permukaan, namun sebaran datanya terbatas. Karakteristik geoteknik fondasi di bawah permukaan harus diketahui dengan cara yang cepat dan efektif.

Pendataan geoteknik terbatas telah dilakukan pada tahun 2019. Salah satunya adalah pendataan rock mass rating (RMR) pada batuan vulkanik dan granitoid secara acak. Karakterisasi RMR ini hanya dapat dilakukan di permukaan, yaitu pada batuan yang tersingkap. Sementara itu, batuan di bawah permukaan yang tidak tersingkap juga harus diketahui sebarannya. Batuan andesit mempunyai kekuatan intact rock tinggi, nilai rebound Schmidt Hammer berkisar antara 66-91,5 (kategori kuat), konversi UCS rata-rata $104 \mathrm{MPa}$, spasi kekar $10 \mathrm{~cm}$ sampai $2 \mathrm{~m}$, frekuensi kekar sekitar 5 buah/meter, pada umumnya bidang kekar tertutup, beberapa terbuka (terisi kuarsa setebal $0,5 \mathrm{~cm}$ ), dan nilai RMR batuan 65. Batuan Diorit Kuarsa sebagian besar tersingkap sebagai bongkahbongkah dengan diameter 1-30 $\mathrm{m}$, jarang terdapat kekar pada bongkah kecuali kekar akibat pelapukan. Nilai rebound Schmidt Hammer berkisar antara 71-88 (kategori kuat) dengan nilai konversi UCS $87 \mathrm{MPa}$, nilai RMR batuan 70 .

Tujuan dari penelitian ini adalah untuk mengetahui kondisi geoteknik bawah permukaan dengan melakukan karakterisasi fondasi untuk menentukan tingkat stabilitas batuan sebagai fondasi bangunan PLTN. Metode geofisika yang digunakan adalah pengukuran seismik refraksi. Pengunaan seismik refraksi untuk pekerjaan geoteknik telah dilakukan pada beberapa penelitian
[10]-[13]. Studi kandidat tapak PLTN menggunakan seismik refraksi telah dilakukan di Mesir [10].

Prinsip pengukuran ini adalah mengetahui kondisi batuan/lapisan batuan di bawah permukaan berdasarkan kecepatan gelombang suara yang dipantulkan dan ditangkap oleh seismograf melalui geofon. Interpretasi data bawah permukaan tersebut kemudian dikorelasikan dengan data geologi untuk memperoleh informasi atau data dasar yang lebih lengkap dan detail mengenai sifat alami dan kesesuaian material bawah permukaan.

\section{METODOLOGI}

Penelitian dilakukan dengan pemetaan geologi dan pengukuran geofisika. Pemetaan geologi dilakukan untuk mengetahui gambaran geologi secara khusus di daerah penelitian. Data geologi yang diperoleh kemudian digunakan sebagai data acuan untuk interpretasi batuan bawah permukaan pada survei geofisika.

Metode geofisika yang digunakan adalah metode seismik refraksi. Metode ini menghitung cepat rambat gelombang seismik dan kedalaman tiap lapisan yang diturunkan dari kurva waktu penjalaran (travel time) sehingga diperoleh model perlapisan batuan bawah permukaan.

Pengambilan data seismik refraksi dilakukan dengan alat ukur seismik multikanal Seismograf DAQlink III (Gambar 2). Alat ini memiliki 24 buah penerima (dalam bentuk geofon). Jarak interval antargeofon yang digunakan adalah $10 \mathrm{~m}$ dan 5 m. Akuisisi disusun menggunakan konfigurasi bentangan geofon end-off spread di kedua ujung bentangan dan mid-spread. Posisi titik tembak (sumber) pada konfigurasi ini berada pada ujung bentangan (baik di kiri maupun di kanan) serta pada bagian tengah 
bentangan geofon. Geofon disusun membentuk lintasan lurus. Data yang diperoleh dari survei seismik refraksi adalah waktu tempuh penjalaran gelombang $\mathrm{P}$ dari sumber ke setiap geofon (travel time).

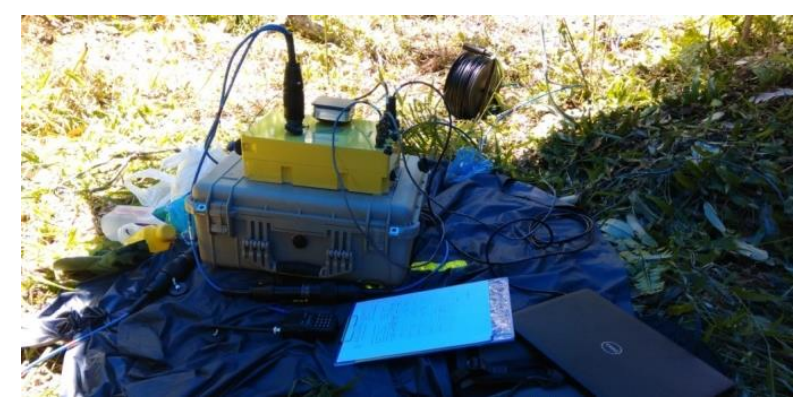

Gambar 2. Seismograf DAQlink III dan beberapa perlengkapannya.

Data elevasi dan posisi diperoleh dengan melakukan pengukuran posisi geofon dan sumber menggunakan bantuan handheld GPS, meteran, dan klinometer pada saat pembuatan lintasan. Perangkat lunak yang digunakan dalam akuisisi data adalah Vibrascope-Seismic Data Acquisition System sedangkan perangkat lunak untuk pengolahan dan interpretasi data adalah Refractor [14]. Filter butterworth band pass sebesar 10-100 $\mathrm{Hz}$ dikenakan terhadap data akuisisi untuk mengeliminasi noise frekuensi tinggi dan rendah. Noise ini dapat menenggelamkan sinyal first break yang nantinya digunakan dalam pengolahan. Interpretasi model batuan bawah permukaan menggunakan metode GRM (Generalized Reciprocal Method) [15]. Hasil penelitian berupa penampang model yang mengklasifikasikan lapisan batuan bawah permukaan berdasarkan kecepatan gelombang kompresi (Vp). Litologi batuan ditentukan berdasarkan nilai $\mathrm{Vp}$ yang menggunakan referensi dari studi hubungan antara konduktivitas termal dan cepat rambat gelombang kompresi pada batuan [16]. Lapisan yang lapuk/lunak dicirikan oleh kecepatan gelombang yang rendah sedangkan lapisan yang segar sebaliknya. Data ini dapat dimanfaatkan untuk penentuan lokasi dan perkiraan kedalaman fondasi yang sesuai.

\section{HASIL DAN PEMBAHASAN}

\section{Geologi Daerah Penelitian}

Daerah bukit Pantai Gosong, berdasarkan pemetaan geologi yang telah dilakukan, didominasi oleh litologi diorit kuarsa dan andesit. Berdasarkan Peta Geologi Regional Lembar Singkawang, terdapat 4 formasi batuan di daerah penelitian yaitu Batuan Gunungapi Raya (Klr), Batuan Terobosan Sintang (Toms), Endapan Litoral (Qc), dan Endapan Aluvial dan Rawa (Qa) [17].

Formasi Batuan Gunung Api Raya berumur Kapur Bawah terdiri atas andesit terubah, dasit, basal dengan gabungan antara piroklastika andesitan dan dasitan, kaya klorit, epidot, sisipan tipis konglomerat, batupasir, dan batulumpur. Formasi Batuan Terobosan Sintang berumur Oligosen terdiri atas diorit, mikrodiorit, granodiorit, diorit kuarsa, gabro kuarsa, dan tonalit. Endapan Litoral berumur Kuarter terdiri atas lumpur, pasir, kerikil, setempat gampingan, dan sisa tumbuhan. Endapan aluvial dan rawa berumur Kuarter terdiri atas lumpur, pasir, kerikil, dan tumbuhan.

Pemetaan geologi di daerah penelitian menunjukkan adanya 4 satuan batuan (Gambar 3), yaitu Satuan Endapan Aluvial atau Rawa (Qa), Satuan Endapan Litoral (Qc), Satuan Diorit Kuarsa, dan Satuan Andesit. Satuan Endapan Aluvial atau Rawa terdapat di sebelah utara dan timur daerah penelitian yang merupakan pemukiman penduduk. Ciri satuan ini adalah memiliki material lepas berukuran pasir dengan fragmen berupa diorit dan andesit. 


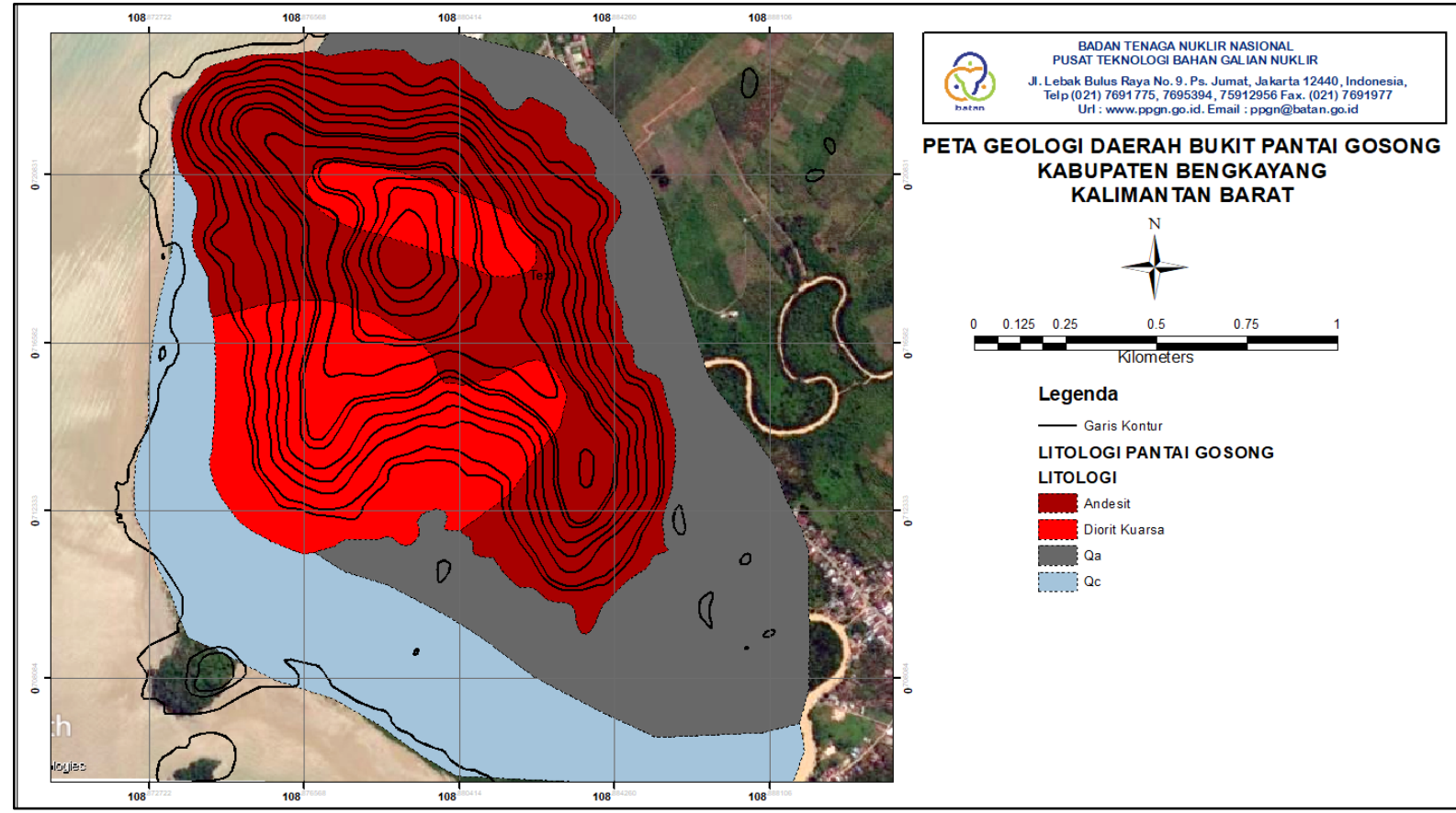

Gambar 3. Peta geologi daerah Pantai Gosong Kabupaten Bengkayang, Kalimantan Barat.

Satuan Endapan Litoral terdapat di sebelah barat daerah penelitian, yaitu sepanjang garis pantai atau daerah pasang surut air laut. Satuan ini dicirikan dengan adanya lumpur dan pasir yang bersifat gampingan. Satuan Diorit Kuarsa terdapat di bagian tengah daerah penelitian. Satuan ini merupakan batuan yang mengintrusi batuan andesit, bertekstur fanerik, terdiri atas mineral feldspar, plagioklas, hornblenda, biotit, dan kuarsa. Secara mikroskopis, sayatan batuan diorit memiliki derajat kristalisasi holokristalin, bentuk mineral relatif subhedral-euhedral, dan memiliki tekstur khusus intergranular (Gambar 4). Pada sayatan ini dijumpai mineral plagioklas 50\%, $\mathrm{K}$-feldspar $5 \%$, piroksen $6 \%$, hornblenda $15 \%$, kuarsa $4 \%$, biotit $15 \%$, dan mineral opak 5\%. Berdasarkan komposisi mineral tersebut batuan dinamakan Quartz Diorite atau Diorit Kuarsa [18].

Satuan Andesit merupakan batuan andesit yang diintrusi oleh diorit kuarsa, berwarna abu-abu, porfiroafanitik, feldspar, piroksen, dan hornblenda. Secara mikroskopis, sayatan batuan andesit memiliki derajat kristalisasi hipokristalin, bentuk mineral relatif subhedral-euhedral, relasi inequigranular porfiritik dengan fenokris tertanam pada massa dasar halus yang kristalin (Gambar 5). Sayatan ini memiliki kandungan mineral plagioklas $40 \%$, piroksen $12 \%$, kuarsa $8 \%$, gelas $5 \%$, mineral opak $3 \%$, massa dasar $25 \%$ dan mineral ubahan yaitu klorit 4\% dan epidot 3\%. Berdasarkan komposisi mineral tersebut batuan dinamakan Andesit [18].

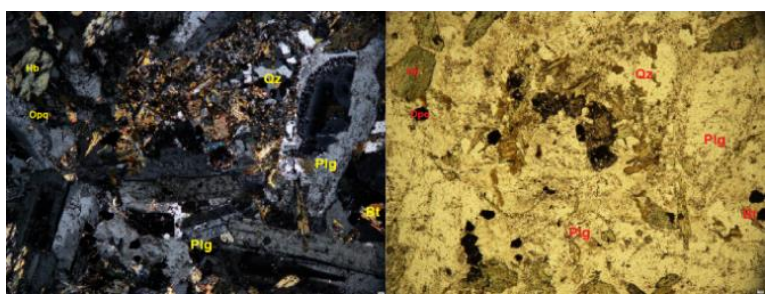

Gambar 4. Kenampakan sayatan tipis diorit pada pengamatan bersilang nikol (kiri) dan sejajar nikol (kanan). 


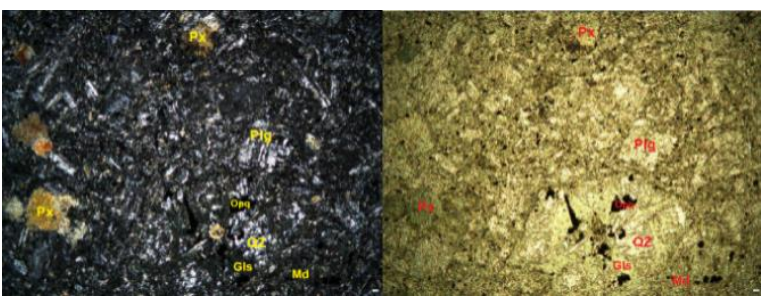

Gambar 5. Kenampakan sayatan tipis andesit pada pengamatan bersilang nikol (kiri) dan sejajar nikol (kanan).

\section{Data Seismik Refraksi}

Peta lokasi pengukuran dibuat dengan mempertimbangkan kondisi geologi, geomorfologi, serta lokasi rencana bangunan PLTN yang telah ditentukan sebelumnya. Peta dibuat berdasarkan kenampakan permukaan bumi yang berasal dari citra satelit. Selain itu, dilakukan survei awal untuk melihat kondisi riil di lapangan. Area penelitian relatif sejajar dengan garis pantai yang ada di bagian baratlaut, serta relatif sejajar dengan arah punggungan/tinggian yang ada di daerah penelitian. Daerah penelitian memanjang dari barat daya ke timur laut. Lintasan utama berarah relatif baratdaya - timurlaut (barat baratdaya - timur timurlaut) sekitar $\mathrm{N} \quad 80^{\circ}$ E. Terdapat 2 lintasan utama yang memotong daerah penelitian secara diagonal. Peta lokasi pengukuran seismik refraksi ditunjukkan oleh Gambar 6.

Proses picking first break dilakukan untuk masing-masing posisi sumber. Pemilihan lapisan dilakukan dengan mempertimbangkan kondisi geologi daerah penelitian (Gambar 7). Litologi batuan ditentukan berdasarkan nilai $\mathrm{Vp}$ yang dihasilkan dari studi hubungan antara konduktivitas termal dan cepat rambat gelombang kompresi pada batuan [16]. Satuan batuan yang berada di lokasi pengukuran adalah satuan batuan diorit kuarsa dan andesit. Nilai Vp dari diorit kuarsa yang masih segar antara $4.900-6.800 \mathrm{~m} / \mathrm{s}$. Nilai Vp untuk andesit segar antara 2.700 $5.400 \mathrm{~m} / \mathrm{s}$. Nilai Vp untuk batuan lapuk dan tanah lebih kecil dari nilai batuan segarnya. Contoh hasil pengolahan dan interpretasi data seismik refraksi pada lintasan PGS11 dapat dilihat pada Gambar 8. Hasil pengolahan untuk lintasan lainnya ditunjukkan pada Gambar 9 dan 10.

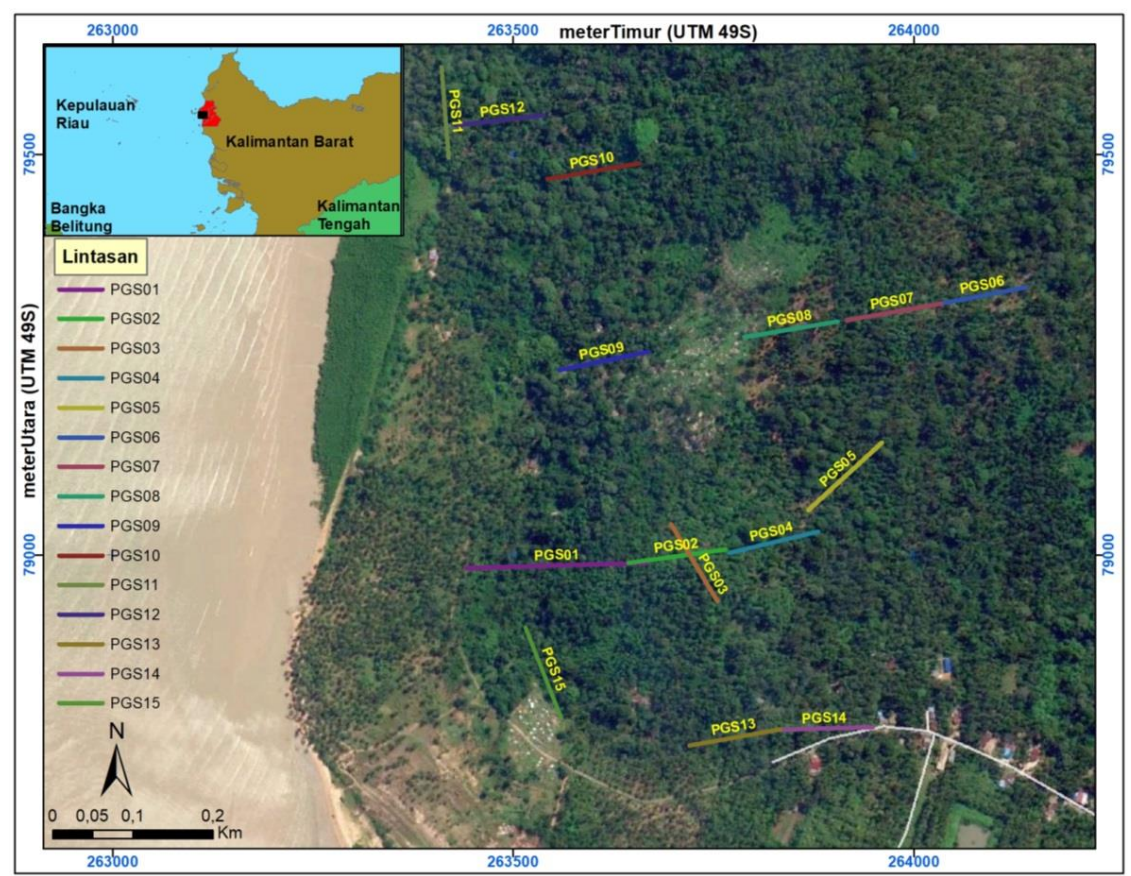

Gambar 6. Peta lokasi pengukuran seismik refraksi di Desa Sungai Raya, Sungai Raya Kepulauan, Bengkayang. 

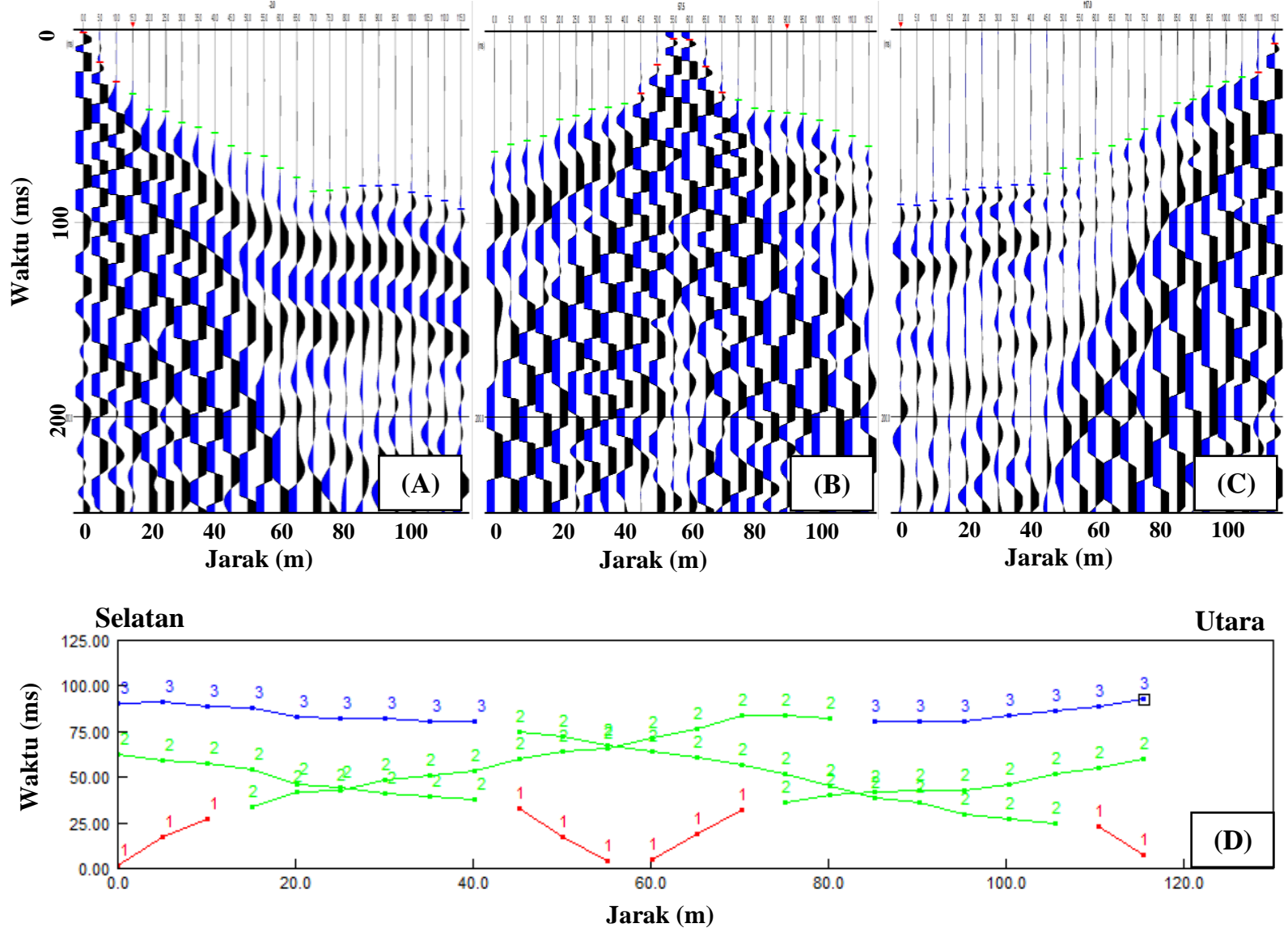

Gambar 7. Contoh data seismik refraksi setelah dilakukan proses picking first break gelombang kompresi untuk lintasan PGS11 untuk posisi sumber pada awal lintasan (A), di tengah lintasan (B), dan di akhir lintasan (C). Hasilnya ditampilkan pada grafik jarak vs waktu (D) dan penentuan lapisan dengan mempertimbangkan kondisi geologi daerah penelitian (Gambar 2).

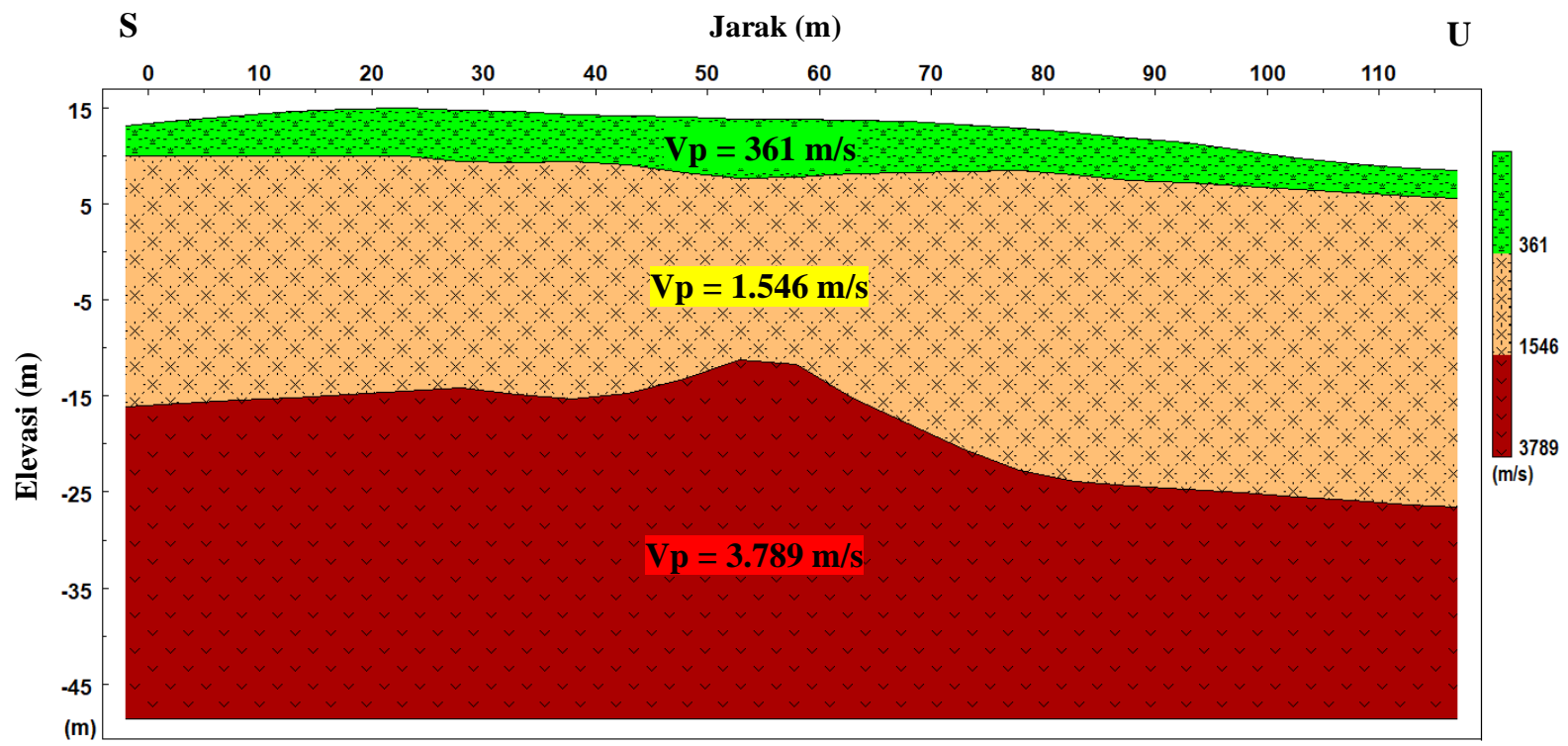

Gambar 8. Model penampang 2 dimensi Vp lapisan batuan bawah permukaan hasil pengolahan dan interpretasi data seismik refraksi untuk Lintasan PGS11 menggunakan metode GRM. 

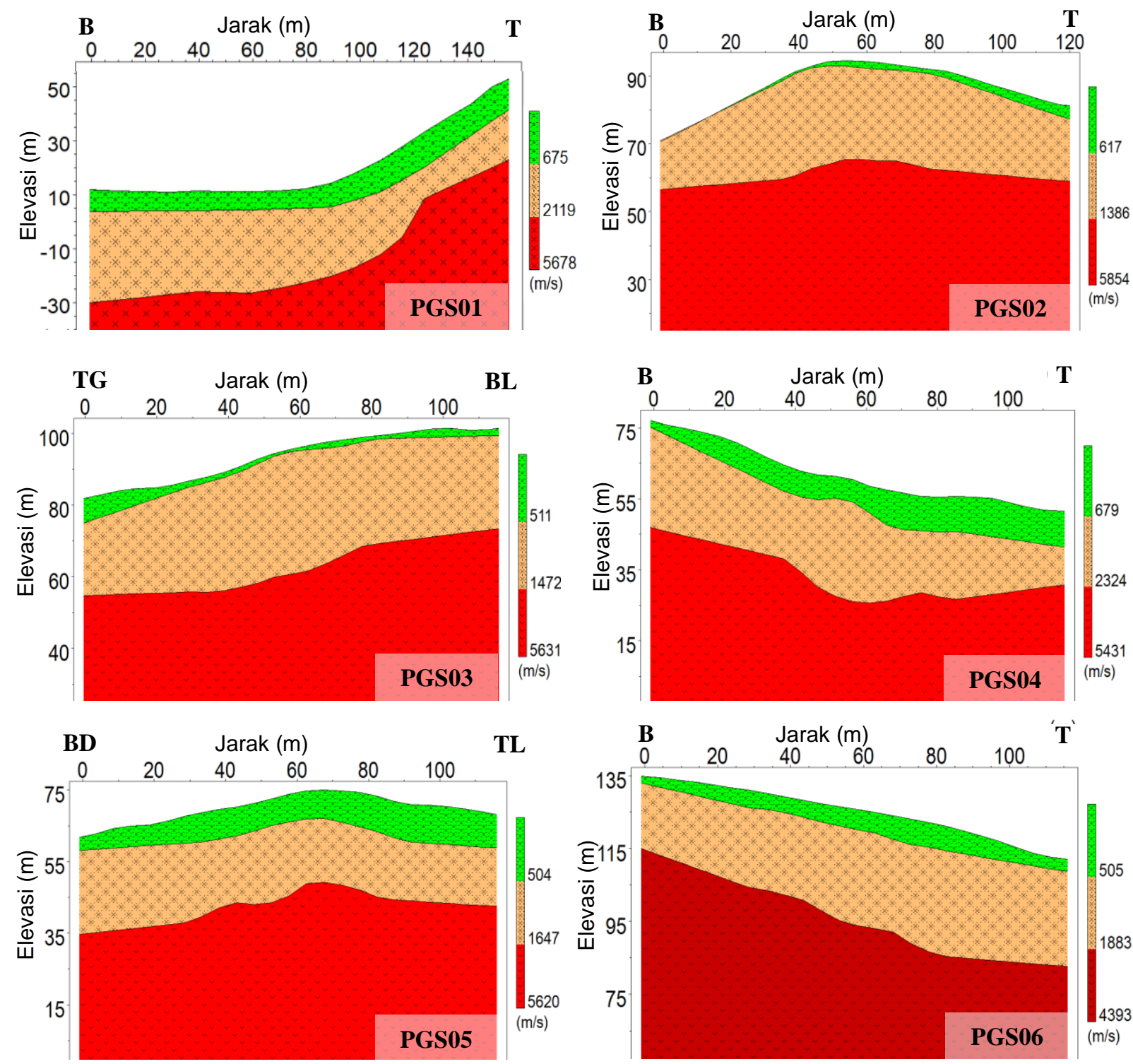

TL
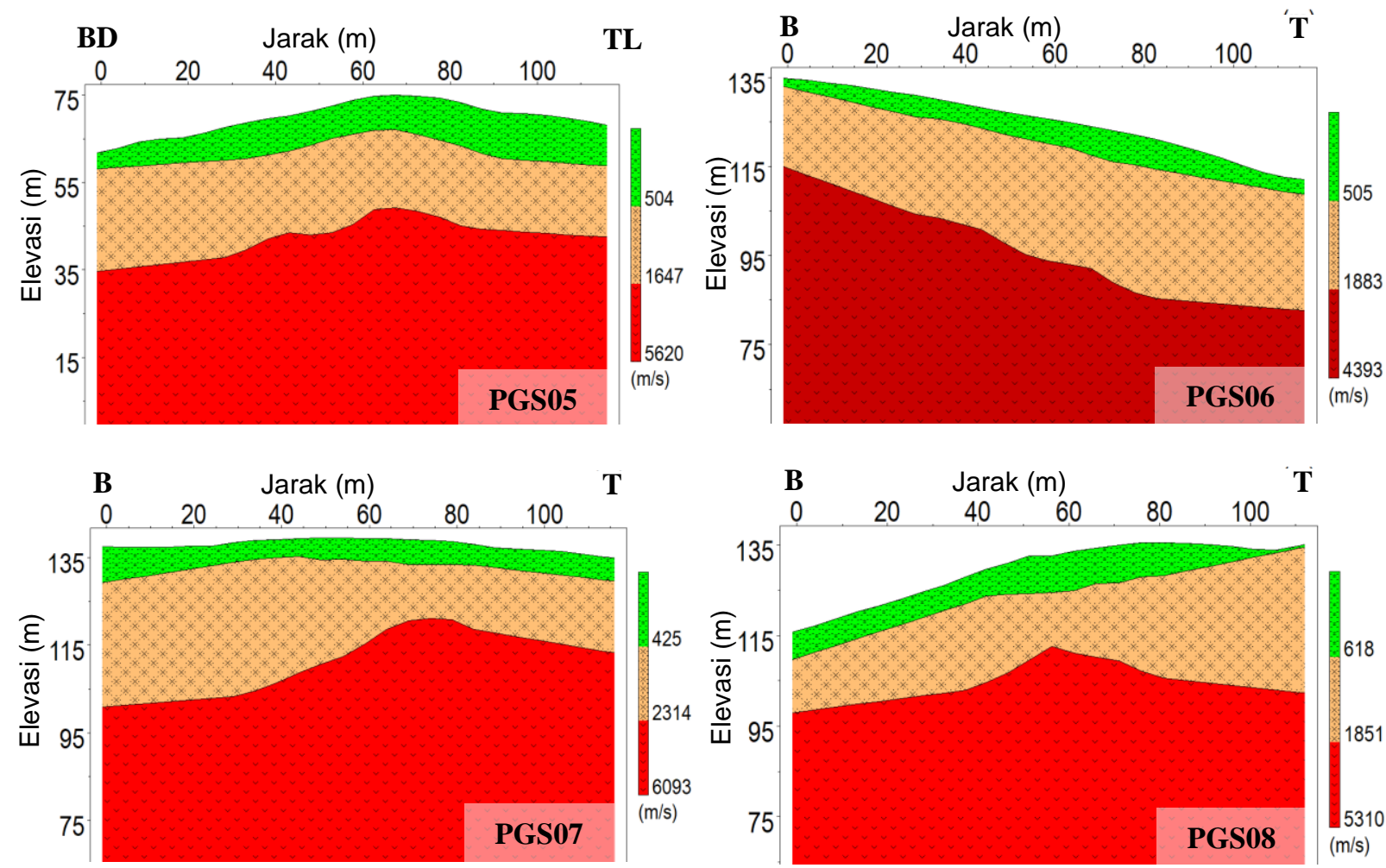

Gambar 9. Model Vp lapisan batuan bawah permukaan hasil pengolahan dan interpretasi data seismik refraksi untuk lintasan PGS01-PGS08 

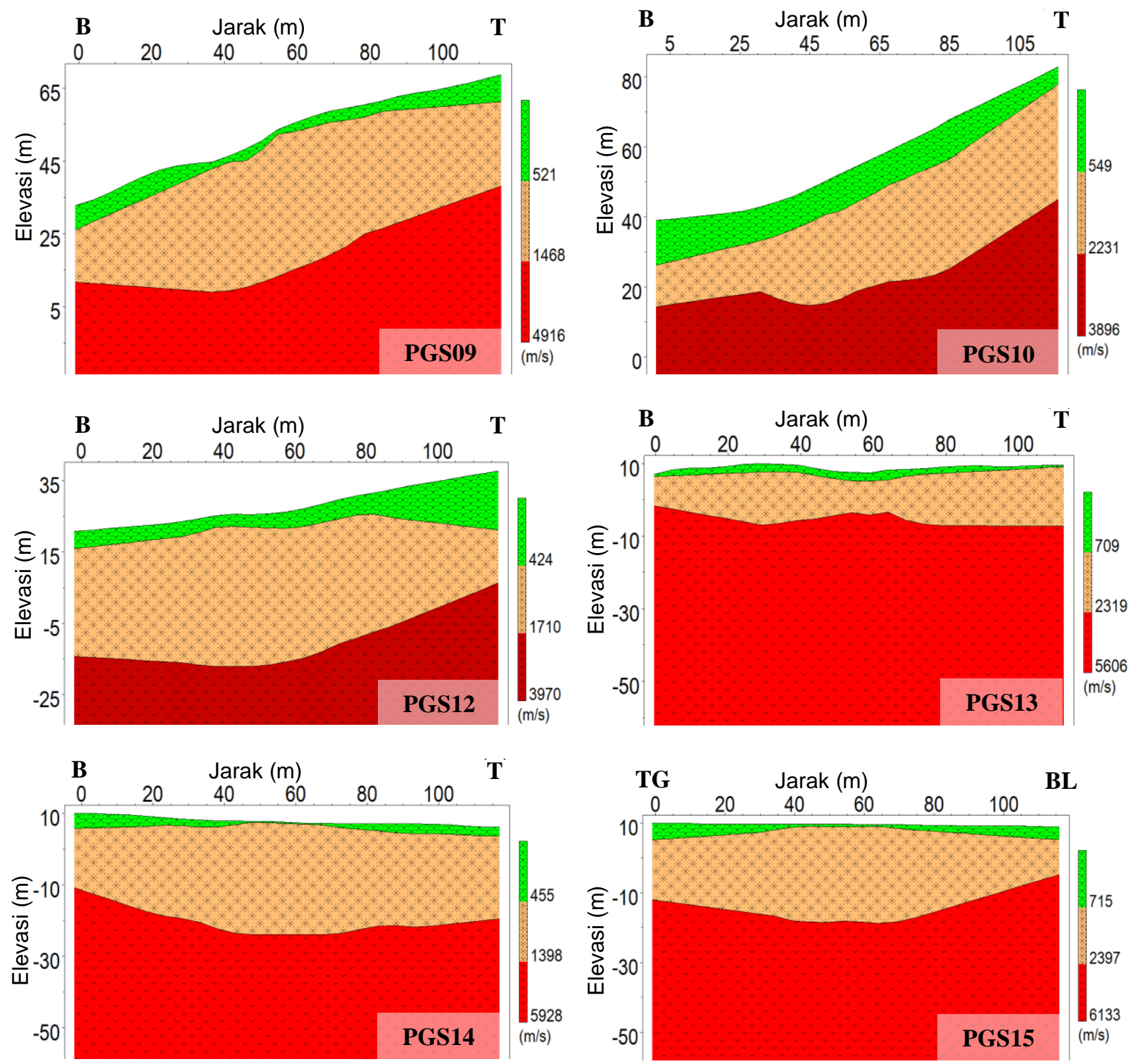

Gambar 10. Model Vp lapisan batuan bawah permukaan hasil pengolahan dan interpretasi data seismik refraksi untuk lintasan PGS09, PGS10, dan PGS12-PGS15

Secara umum terdapat 3 lapisan batuan pada lintasan PGS11. Lapisan pertama merupakan lapisan tanah atau lapukan dari batuan yang disertai adanya bongkahbongkah batuan yang muncul sampai ke permukaan. Nilai Vp lapisan pertama adalah sekitar $361 \mathrm{~m} / \mathrm{s}$. Lapisan kedua merupakan lapisan batuan lapuk dan batuan yang mengalami frakturasi cukup kuat. Nilai Vp untuk lapisan kedua sekitar $1.546 \mathrm{~m} / \mathrm{s}$.
Lapisan ketiga merupakan lapisan batuan yang masih segar. Lapisan ketiga memiliki nilai Vp sekitar $3.789 \mathrm{~m} / \mathrm{s}$. Nilai Vp pada lapisan ini sesuai dengan litologi batuan yang berada pada satuan batuan andesit. Fondasi bangunan yang ideal sampai ke lapisan batuan ketiga ini. Nilai Vp untuk seluruh lintasan seismik refraksi beserta ketebalan dan kedalaman batuannya dapat dilihat pada Tabel 1. 
Tabel 1. Nilai kecepatan seismik dan rentang ketebalan untuk lapisan pertama dan kedua, kecepatan seismik dan kedalaman batuan dari permukaan untuk lapisan ketiga, serta satuan batuan segar untuk masing-masing lapisan dari hasil pengolahan dan interpretasi data seismik refraksi

\begin{tabular}{|c|c|c|c|c|c|c|c|c|}
\hline \multirow[b]{2}{*}{ No } & \multirow[b]{2}{*}{ Lintasan } & \multicolumn{2}{|c|}{ Lapisan 1} & \multicolumn{2}{|c|}{ Lapisan 2} & \multicolumn{2}{|c|}{ Lapisan 3} & \multirow{2}{*}{$\begin{array}{c}\text { Satuan Batuan } \\
\text { Segar }\end{array}$} \\
\hline & & $\begin{array}{c}V p_{1} \\
(\mathrm{~m} / \mathrm{s})\end{array}$ & $\begin{array}{l}\text { Ketebalan } \\
(\mathrm{m})\end{array}$ & $\begin{array}{c}V p_{2} \\
(\mathrm{~m} / \mathrm{s})\end{array}$ & $\begin{array}{l}\text { Ketebalan } \\
(\mathrm{m})\end{array}$ & $\begin{array}{c}V p_{3} \\
(\mathrm{~m} / \mathrm{s})\end{array}$ & $\begin{array}{c}\text { Kedalaman } \\
(\mathrm{m})\end{array}$ & \\
\hline 1 & PGS01 & 675 & $6-13$ & 2.119 & $11-33$ & 5.678 & $25-42$ & diorit kuarsa \\
\hline 2 & PGS02 & 617 & $1-4$ & 1.386 & $14-30$ & 5.854 & $25-31$ & diorit kuarsa \\
\hline 3 & PGS03 & 511 & $1-7$ & 1.472 & $20-35$ & 5.631 & $27-35$ & diorit kuarsa \\
\hline 4 & PGS04 & 679 & $2-11$ & 2.324 & $11-29$ & 5.431 & $21-34$ & diorit kuarsa \\
\hline 5 & PGS05 & 504 & $4-11$ & 1.647 & $16-23$ & 5.620 & $25-30$ & diorit kuarsa \\
\hline 6 & PGS06 & 505 & $2-7$ & 1.883 & $18-29$ & 4.393 & $20-36$ & andesit \\
\hline 7 & PGS07 & 425 & $4-8$ & 2.314 & $13-31$ & 6.093 & $18-36$ & diorit kuarsa \\
\hline 8 & PGS08 & 618 & $1-9$ & 1.851 & $12-32$ & 5.310 & $18-33$ & diorit kuarsa \\
\hline 9 & PGS09 & 521 & $2-8$ & 1.468 & $15-39$ & 4.916 & $21-41$ & diorit kuarsa \\
\hline 10 & PGS10 & 549 & $5-13$ & 2.231 & $12-33$ & 3.896 & $24-43$ & andesit \\
\hline 11 & PGS11 & 361 & $3-6$ & 1.546 & $19-32$ & 3.789 & $25-36$ & andesit \\
\hline 12 & PGS12 & 424 & $3-17$ & 1.710 & $15-39$ & 3.970 & $32-43$ & andesit \\
\hline 13 & PGS13 & 709 & $0-3$ & 2.319 & $8-17$ & 5.606 & $9-17$ & diorit kuarsa \\
\hline 14 & PGS14 & 455 & $1-4$ & 1.398 & $16-31$ & 5.928 & $21-32$ & diorit kuarsa \\
\hline 15 & PGS15 & 715 & $1-5$ & 2.397 & $10-27$ & 6.133 & $14-29$ & diorit kuarsa \\
\hline
\end{tabular}

Lintasan seismik refraksi sebagian besar berada di atas batuan diorit kuarsa yang berada di bagian atas bukit Pantai Gosong. Secara umum, berdasarkan interpretasi model penampang 2 dimensi lapisan batuan bawah permukaan, material bawah permukaan dapat dibagi dalam 3 lapisan yaitu tanah, batuan beku lapuk, dan batuan beku segar. Batuan beku yang terdapat di daerah penelitian adalah diorit kuarsa dan andesit.

Satuan batuan diorit kuarsa terdapat pada 11 lintasan seismik, sedangkan satuan batuan andesit terdapat pada 4 lintasan seismik. Nilai Vp untuk diorit kuarsa berkisar antara 4.916$6.133 \mathrm{~m} / \mathrm{s}$. Nilai Vp untuk andesit berkisar antara 3.789-4.393 m/s. Lapisan pertama berupa tanah memiliki nilai $\mathrm{Vp}$ antara 361$715 \mathrm{~m} / \mathrm{s}$ dengan ketebalan 0-17 m. Lapisan kedua yang merupakan lapisan batu lapuk atau batuan yang mengalami frakturasi yang kuat (baik pada diorit kuarsa maupun andesit) memiliki nilai Vp berkisar antara 1.386$2.397 \mathrm{~m} / \mathrm{s}$ dengan ketebalan antara $8 \mathrm{~m}$ sampai $39 \mathrm{~m}$. Lapisan kedua memiliki nilai Vp yang cukup tinggi diduga akibat adanya batuan segar yang berupa bongkah yang bercampur dengan batuan yang mengalami pelapukan. Lapisan ketiga dengan nilai Vp berkisar antara $3.789-6.133 \mathrm{~m} / \mathrm{s}$ diduga sebagai lapisan batuan beku segar dan memiliki kedalaman mulai dari 9 m sampai $43 \mathrm{~m}$ dari permukaan tanah.

Elastisitas dan densitas batuan mempengaruhi nilai Vp dalam lapisan batuan. Semakin besar nilai Vp maka semakin besar juga nilai densitas batuan. Densitas batuan dapat ditentukan dengan menggunakan rumus empiris yang diambil dari Gardner's relationship, dengan menggunakan $\mathrm{Vp}$ untuk memprediksikan densitas suatu batuan [19]. Serangkaian studi empiris dilakukan sehingga diperoleh hubungan antara kecepatan dan densitas batuan seperti pada persamaan (1).

$$
\rho=a V p^{1 / 4}
$$


dengan

$$
\begin{aligned}
\rho & =\text { densitas batuan }\left(\mathrm{g} / \mathrm{cm}^{3}\right) \\
a & =0,31 \\
V p & =\text { kecepatan gelombang kompresi }(\mathrm{m} / \mathrm{s})
\end{aligned}
$$

Hasil perhitungan densitas batuan berdasarkan persamaan Gardner ditunjukkan pada Tabel 2.

Tabel 2. Nilai densitas batuan hasil perhitungan menggunakan persamaan Gardner

\begin{tabular}{ccccc}
\hline $\begin{array}{c}\text { Jenis } \\
\text { Medium }\end{array}$ & $\begin{array}{c}V p_{\min } \\
(\mathrm{m} / \mathrm{s})\end{array}$ & $\begin{array}{c}V p_{\max } \\
(\mathrm{m} / \mathrm{s})\end{array}$ & $\begin{array}{c}\text { Densitas } \\
\left(\mathrm{g} / \mathrm{cm}^{3}\right)\end{array}$ & $\begin{array}{c}\text { Densitas } \\
\left(\mathrm{g} / \mathrm{cm}^{3}\right)\end{array}$ \\
\hline Tanah & 361 & 715 & 1,35 & 1,60 \\
$\begin{array}{c}\text { Batuan } \\
\text { Beku } \\
\text { Lapuk }\end{array}$ & 1.386 & 2.397 & 1,89 & 2,17 \\
$\begin{array}{c}\text { Diorit } \\
\text { Kuarsa }\end{array}$ & 3.789 & 4.393 & 2,43 & 2,52 \\
Andesit & 4.916 & 6.133 & 2,60 & 2,74 \\
\hline
\end{tabular}

\section{KESIMPULAN}

Hasil pemetaan geologi di lokasi penelitian menunjukkan adanya 2 satuan batuan beku yaitu Satuan Diorit Kuarsa dan Satuan Andesit. Hasil pengolahan dan interpretasi data seismik refraksi menghasilkan model penampang 2 dimensi cepat rambat gelombang kompresi pada lapisan batuan bawah permukaan. Terdapat 3 lapisan batuan di lokasi penelitian yaitu lapisan tanah, lapisan batuan beku lapuk, dan lapisan batuan beku segar. Nilai kecepatan gelombang kompresi (Vp) tanah 361-715 $\mathrm{m} / \mathrm{s}$, batuan beku lapuk 1.386-2.397 m/s, dan batuan beku segar $3.789-6.133 \mathrm{~m} / \mathrm{s}$. Perkiraan densitas batuan beku segar berdasarkan perhitungan dari persamaan Gardner adalah 2,43-2,74 $\mathrm{g} / \mathrm{cm}^{3}$. Hasil pemodelan menunjukkan kedalaman lapisan batuan beku segar di lokasi penelitian antara $9 \mathrm{~m}$ sampai 43 m. Lapisan batuan beku segar pada kedalaman tersebut ideal untuk dijadikan sebagai fondasi bangunan PLTN.

\section{UCAPAN TERIMA KASIH}

Terima kasih penulis sampaikan kepada Lembaga Pengelola Dana Pendidikan (LPDP)-Kementerian Keuangan yang telah mendanai penelitian ini. Terima kasih kepada Bapak Yarianto Sugeng Budi Susilo selaku Plt. Kepala Pusat Riset dan Teknologi Bahan Galian Nuklir, Erwina Aminarthi yang telah melakukan analisis petrografi, dan semua pihak yang terlibat. Semua penulis memiliki kontribusi yang sama sebagai kontributor utama di dalam penyusunan manuskrip ini.

\section{DAFTAR PUSTAKA}

[1] H. Susiati, I. G. Sukadana, Y. S. Budi Susilo, and Y. Yuliastuti, "Land Suitability Determination of NPP's Potential Site in East Kalimantan Coastal Using GIS,” J. Pengemb. Energi Nukl., vol. 21, no. 1, p. 53, 2019.

[2] H. Suntoko, "Identifikasi Daerah Interes Calon Tapak Pltn Kalimantan Barat Berdasarkan Kriteria Umum," Eksplorium Bul. Pus. Teknol. Bahan Galian Nukl., vol. 35, no. 1, pp. 57-68, 2014.

[3] H. Susiati, "Penentuan Tapak Potensial PLTN dengan Metode SIG di Wilayah Pesisir Propinsi Kalimantan Barat," J. Pengemb. Energi Nukl., vol. 16, no. 2, pp. 131-142, 2014.

[4] E. E. Alhakim, H. Susiati, and Sunarko, "Analisis Spasial Awal Lokasi Calon Tapak PLTN di Kalimantan Barat," Pros. Semin. Nas. Infrastruktur Energi Nukl., pp. 173-179, 2019.

[5] I. Bastori and Sriyana, "Analisis Risiko Proyek PLTN Kalbar dengan Pendekatan Model AHP dan PMBOK," J. Pengemb. Energi Nukl., vol. 22, no. 1, pp. 39-44, 2020.

[6] N. Herawati and A. D. Sudagung, "Persepsi Masyarakat dan Potensi Public Acceptance Terkait Wacana Pembangunan PLTN di Kabupaten Bengkayang," J. Pengemb. Energi Nukl., vol. 22, no. 2, p. 111, 2020.

[7] F. N. Hussein et al., "Potensi Bahaya Gunung Api Terhadap Calon Tapak PLTN, Studi Kasus: Gunung Api Semadum, Kalimantan Barat," J. Pengemb. Energi Nukl., vol. 22, no. 2, p. 89, 2020.

[8] H. Priyanto, M. Mudjiono, and S. Yosomulyono, "Koreksi Geometrik Pemetaan Tataguna Lahan di Sekitar Calon Tapak PLTN Kalimantan Barat,” $J$. 
Pengemb. Energi Nukl., vol. 23, no. 1, p. 61, 2021.

[9] M. Mudjiono, S. Alimah, and H. Susiati, "Identifikasi Perubahan Tataguna Lahan di Sekitar Calon Tapak PLTN Kabupaten Bengkayang, Kalimantan Barat," J. Pengemb. Energi Nukl., vol. 22, no. 2, p. 101, 2020.

[10] A. M. Abudeif, A. E. Raef, A. A. Abdel Moneim, M. A. Mohammed, and A. F. Farrag, "Dynamic Geotechnical Properties Evaluation of a Candidate Nuclear Power Plant Site (NPP): Pand S-Waves Seismic Refraction Technique, North Western Coast, Egypt," Soil Dyn. Earthq. Eng., vol. 99, no. May, pp. 124-136, 2017.

[11] S. Shebl, K. S. Gemail, M. Attwa, S. A. Soliman, A. Azab, and M. H. Farag, "Utilizing shallow seismic refraction in defining the geotechnical properties of the foundation materials: A case study at New Minia City, Nile Valley, Egypt," Egypt. J. Pet., vol. 28, no. 2, pp. 145-154, 2019.

[12] A. M. E. Mohamed, A. S. A. Abu El Ata, F. Abdel Azim, and M. A. Taha, "Site-specific shear wave velocity investigation for geotechnical engineering applications using seismic refraction and 2D multi-channel analysis of surface waves," NRIAG J. Astron. Geophys., vol. 2, no. 1, pp. 88101, 2013.

[13] M. H. Khalil and S. M. Hanafy, "Engineering applications of seismic refraction method: A field example at Wadi Wardan, Northeast Gulf of
Suez, Sinai, Egypt," J. Appl. Geophys., vol. 65, no. 3-4, pp. 132-141, 2008.

[14] Geogiga Technology Corp., Refractor 8.3 User Guide. Alberta, Canada, 2017.

[15] D. Palmer, "An introduction to the generalized reciprocal method of seismic refraction interpretation.," Geophysics, vol. 46, no. 11, pp. 1508-1518, 1981.

[16] P. Mielke, K. Bär, and I. Sass, "Determining the relationship of thermal conductivity and compressional wave velocity of common rock types as a basis for reservoir characterization," $J$. Appl. Geophys., vol. 140, no. October, pp. 135144, 2017.

[17] N. Suwarna and R. Langford, Peta Geologi Lembar Singkawang, Kalimantan. Bandung: P3G ESDM, 1993.

[18] A. L. Streckeisen, "IUGS Subcommission on the Systematics of Igneous Rocks: Classification and Nomenclature of Volcanic Rocks, Lamprophyres, Carbonatites and Melilite Rocks: Recommendations and Suggestions," Neues Jahrb. fur Mineral. Abhandlungen, vol. 141, pp. 1-14, 1978.

[19] G. H. F. Gardner, L. W. Gardner, and A. R. Gregory, "Formation Velocity and Density - The Diagnostic Basics for Stratigraphic Traps," Geophysics, vol. 39, pp. 770-780, 1974. 